\title{
Outcomes from Experimental Testing of Nonsteroidal Anti-Inflammatory Drug (NSAID) Administration during the Transition Period of Dairy Cows
}

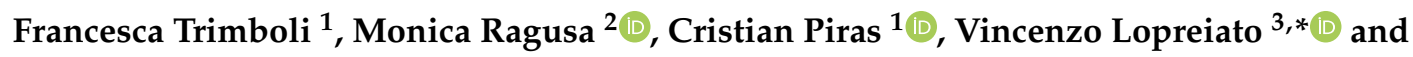 \\ Domenico Britti ${ }^{1}$ (D) \\ 1 Department of Health Science, Magna Græcia University, 88100 Catanzaro, Italy; trimboli@unicz.it (F.T.); \\ c.piras@reading.ac.uk (C.P.); britti@unicz.it (D.B.) \\ 2 Department of Experimental and Clinical Medicine, Magna Græcia University, 88100 Catanzaro, Italy; \\ m.ragusa@unicz.it \\ 3 Department of Animal Sciences, Food and Nutrition, Faculty of Agriculture, Food and Environmental \\ Science, Università Cattolica del Sacro Cuore, 29122 Piacenza, Italy \\ * Correspondence: vincenzo.lopreiato@unicatt.it
}

Received: 30 June 2020; Accepted: 2 October 2020; Published: 8 October 2020

Simple Summary: The treatment of dairy cows with nonsteroidal drugs is applied experimentally to investigate the relevance of inflammation during the periparturient period. Despite appearing healthy, dairy cows throughout the transition period and mainly after parturition can develop a pro-inflammatory status that may negatively influence milk production and cows' health. The administration of nonsteroidal anti-inflammatory drugs (NSAIDs) has been demonstrated to have both positive or negative effects on health and milk production, depending on the type of inhibition mechanism, the dose administered and the cows' lactation numbers. At present, the safety and efficacy of NSAIDs have not been irrefutably demonstrated; therefore, their use to improve metabolic and inflammatory status, as well as milk production and cow health after parturition, should be carefully evaluated.

Abstract: During the transition period, dairy cows experience great physiological stress caused by changes in metabolism and in the immune and endocrine systems. A pro-inflammatory state is another difficulty faced by even apparently healthy animals. The most significant negative consequences of inflammation in dairy cows are substantial impairment of milk production and deleterious effects on cows' health in extreme cases. Nonetheless, a certain degree of inflammation is necessary to sustain physiological adaptations. In recent years, many studies have attempted to determine whether the use of nonsteroidal anti-inflammatory drugs (NSAID) in the transition period of dairy cows could positively affect milk production and cows' health by controlling the inflammation status. This literature indicates that NSAIDs that act as preferential inhibitors of cyclooxygenase-1 (COX-1) activity show important side effects (e.g., increased risk of retained placenta, culling, or metritis) even if milk production is, on average, ameliorated. In contrast, preferential inhibitors of cyclooxygenase- 2 (COX-2) activity have overall positive effects on cows' health, with potential beneficial effects on milk production. Furthermore, it is important to note that with certain NSAID treatments, milk discarding is mandatory to prevent contamination with drug residues, but increased milk production can compensate for the loss of milk revenue during the withdrawal period.

Keywords: NSAID; transition period; milk production; cow health 


\section{Introduction}

The transition period (TP), the most critical physiological stage in dairy cattle, starts 3 weeks before parturition and finishes 3 weeks thereafter. It is a critical physiological phase for dairy cattle due to the major changes that occur in metabolism, immune systems, and endocrine system [1]. During this period, dairy cows often experience a negative energy balance (NEB) and micronutrient deficiencies [2]. A NEB in transition cows is mainly caused by two phenomena: First, immediately after parturition, the energy requirements dairy cows rapidly increases due to enormous milk secretion; and second, there is a concurrent significant reduction in feed intake [3,4]. Lactogenesis induces an increase in body fat mobilization toward the mammary glands and a subsequent increase in serum NEFA and BHB levels [5]. Both hypoglycemia and hypocalcemia are common, because glucose and calcium are taken up by the mammary gland [6]. This programmed metabolic shift is an example of homeorhesis, namely, the "coordinated changes in metabolism of body tissues necessary to support a physiological state" [7]. Homeorhetic changes occurring during TP cause alterations in circulating metabolites, hormones, and neuroendocrine factors which sustain and drive variations in tissue functions and remodeling, and metabolic flux $[6,8]$.

Mammary gland tissue remodeling facilitates the entry of microorganisms and thereby actives the innate immune system, attracting neutrophils, macrophages, and dendritic cells $[9,10]$. Indeed, dairy cows around parturition are more susceptible to mastitis [11]. In turn, immune cells produce high levels of pro-inflammatory cytokines such as interleukine-1 $\beta$ (IL-1 $\beta$ ), interleukine-6 (IL-6), and tumor necrosis factor- $\alpha(\mathrm{TNF}-\alpha)[9,10]$. A pro-inflammatory state is another difficulty faced by dairy cows during TP, and is well documented in several other species, such as pig [12,13], mice [14], and human [15].

Inflammation is an evolutionarily conserved biological process occurring in response to pathological stimuli, such as tissue injury or infection. It serves in the clearance of pathogens and the resolution of infection, but can also cause deleterious effects on animals' health and production when excessive or out of control.

Several studies have experimented with the use of nonsteroidal anti-inflammatory drugs (NSAID) during the transition period of dairy cows in order to control the inflammation state. Bertoni et al. [16] observed that the administration of salicylic acid immediately after calving improved, during the first two months, milk production and first-service pregnancy rate. Another NSAID, carprofen, administered for 3 to 4 weeks after calving increased conception rates, but did not affect milk production [17].

The presence of an inflammatory state in postpartum dairy cows is particularly well established. Interestingly, many authors have demonstrated that inflammatory markers and acute-phase proteins increase in cows immediately after parturition, even in apparently healthy animals [18-22], suggesting that parturition and lactogenesis could directly induce a pro-inflammatory status. An alternative to this scenario is that bacterial infections and related endotoxins could affect far more postpartum cows than is currently recognized. It is well established that inflammation is associated with common peripartum diseases. For example, cows affected by fatty liver have elevated plasma concentrations of haptoglobin and serum amyloid A, acute-phase proteins [23] and proinflammatory cytokine TNF- $\alpha$ activity [24]. The difficulty is how to interpret the inflammation-disease association. Indeed, inflammation can contribute to the development of some peripartum disorders (disease cause), but it also possible that subclinical and undiagnosed conditions provoke an elevation of inflammation mediators before diagnosis (disease effect) [25].

As suggested by observational and controlled studies, an important negative consequence of inflammation in dairy cows is a substantial impairment of milk production. Bionaz et al. [19] reported that transition dairy cows with high paraoxonase levels, a negative acute-phase protein, produced about $24 \%$ more milk for lactation compared to transition dairy cows with lower paraoxonase levels. Conversely, Huzzey et al. [26] observed that cows with higher concentrations of haptoglobin, a positive acute-phase protein, produced less milk. The administration of TNF- $\alpha$ to dairy cows during the first week of lactation causes a decrease of about $15 \%$ of milk production [27]. Hence, inflammation shows deleterious effects on dairy cows' health in TP when it is excessive and not controlled. There is 
some evidence that proves that a certain degree of inflammation is necessary to sustain physiological adaptations in TP.

Parturition is facilitated by inflammation; for example, prostaglandin $\mathrm{F}_{2 \alpha}$ production is mediated by cyclooxygenases, and increases oxytocin receptor expression in the uterus, allowing oxytocin-induced uterine contractions to occur [28]. However, the administration of nonsteroidal anti-inflammatory drugs (NSAID) like aspirin or flunixin meglumine can increase the risk of retained placenta [25].

Milk production could benefit from a low degree of inflammation. It has been speculated that insulin resistance, the key mechanism that diverts nutrient flux from adipose tissue and muscle to the mammary glands, is probably promoted by a certain degree of inflammation [25].

Finally, as mentioned above, inflammation helps dairy cows to fight infections that could occur in early lactation [29].

\section{The Use of NSAIDs during Transition Period of Dairy Cows}

In light of the evidence provided above, inflammation becomes a serious problem for the health of dairy cows in TP when it is excessive and out of control. Numerous studies have investigated the use of several nonsteroidal drugs (NSAID) in the TP of dairy cows to positively affect milk production and the health of cows by controlling the inflammation status [25,30-33].

NSAIDs act on several prostaglandin pathways. It is known that while cyclooxygenase (COX)-1 acts mainly on daily physiological functions, the function of COX-2 normally acts in specific conditions such as inflammation [34]. Therefore, the therapeutic action of NSAID drugs derives from their ability to inhibit COX-2, while most of the side effects (gastrointestinal irritation, renal toxicity, and inhibition of blood clotting) associated with the use of NSAID are caused by the inhibition of COX-1 [35]. Each NSAID drug acts differently on COX-1 and COX-2. For example, Flunixin meglumine (FM) acts as an inhibitor of both COX-1 and COX-2, with greater selectivity towards COX-1 in horses [36]. Ketoprofen also inhibits both COX-1 and COX-2, showing greater activity as a COX-1 inhibitor [37]. Although both ketoprofen and FM have a prevalent activity on COX-1, the side effects caused by Ketoprofen are minor, due to the short period of time in which ketoprofen remains in circulation compared to FM.

Meloxicam is known to be a preferential COX-2 inhibitor [36], having a targeted action against inflammatory processes and reducing the possibility of experiencing serious side effects, such as placental retention [38].

This review summarizes current knowledge about the effects of NSAIDs on the TP of dairy cows, with regards to the animals' health status and production. A special section is dedicated to a nonconventional drug utilized in transition dairy cows to improve immune defenses, i.e., pegbovigrastim, a granulocyte colony-stimulating factor.

\subsection{Salicylates}

NSAID drugs have been used in the veterinary field since 1875; the first such compound was salicylic acid (SS), a phenolic molecule extracted from willow bark. SS acts by inhibiting COX-1 and -2 activity [39] through transcriptional factor NF- $\mathrm{kB}$ inhibition [40]. The plasma half-life of SS in cows is approximately $30 \mathrm{~min}$ [25], so a milk withdrawal time of $24 \mathrm{~h}$ is considered adequate to avoid residues contaminating the milk [41] (Table 1).

In recent years, an increasing number of studies on transition period dairy cows have investigated the effects of SS administration on health status and milk production. Bertoni et al. [16] conducted the first study that demonstrated milk yield increment and a reduction of plasma acute phase protein levels, e.g., haptoglobin and ceruloplasmin, in multiparous cows treated in the first 5 days of lactation with lysine acetyl salicylate. 
Table 1. Principal qualitative aspects of nonsteroidal anti-inflammatory drugs (NSAIDs).

\begin{tabular}{cccc}
\hline Drug & Target & Half Time & Milk Withdrawal \\
\hline Salicylate & COX-1/2 & $0.5 \mathrm{~h}$ & $24 \mathrm{~h}$ \\
Flunexin meglumine & COX-1 preferential & $1.6 \mathrm{~h}$ & $36-48 \mathrm{~h}$ \\
Meloxicam & COX-2 preferential & $26 \mathrm{~h}$ & $120 \mathrm{~h}(0.5 \mathrm{mg} / \mathrm{kg} \mathrm{BW,} \mathrm{i.m.)}$ \\
Carprofen & COX-2 selective & $30.7 \mathrm{~h}$ & or $80 \mathrm{~h}(1 \mathrm{mg} / \mathrm{kg} \mathrm{BW}, \text { os })^{\text {Not required }^{1}}$ \\
\hline
\end{tabular}

${ }^{1}$ in European countries; i.m.: intramuscular; os: oral.

Subsequent studies have confirmed the results of Bertoni's study by further explaining how the effects of SS on milk production are influenced by both parity and the basal state of inflammation [31,42-44]. Farney et al. [42] enrolled in their study both primiparous and pluriparous cows to which SS $(\approx 123 \mathrm{~g} / \mathrm{d})$ was administered in water for 7 days. The SS treatment accelerated the early lactation increase in milk fat secretion, leading to an exacerbated negative energy balance as demonstrate by NEFA and BHBA increment and glucose decrement, according to Bertoni et al. (2004), but not milk yield. In a more detailed study, Farney et al. [43] observed a $21 \%$ and $14 \%$ increment of milk yield and milk total proteins per lactation in SS-treated, third lactation cows; such a phenomenon had not been described previously [42]. The explanation for this apparent discrepancy, even though experimental conditions were similar, may be the fact that authors in the first study [42] did not classify cows according to parity, thereby likely losing the possibility of observing differences in milk yield, as reported also by Bertoni et al. [16], and increased milk protein yield. Some evidence indicates that multiparity increases inflammatory pressure [45], so it is possible to hypothesize that SS treatment could promote milk production (see Table 2 for more details on the experimental methods).

A certain degree of inflammation is necessary to support physiological adaptations in the transition period, but an excess has deleterious effects on milk production. Evidence supporting this hypothesis is provided by the observation of how the presence or absence of an increment in milk yield, milk composition, or milk component yields associated with SS treatment is associated with a different degree of inflammation that cattle experienced at calving, measured as mean haptoglobin concentrations. In one study [44], haptoglobin concentrations were much less than those measured at similar time points in the previous study [31]. Both studies followed the same experimental scheme but the results of milk yield and milk component yields were opposite: in cows with lower haptoglobin concentrations, no differences were observed, whereas in cows with higher haptoglobin concentrations, sustained increases in milk yield were observed in SS cows with respect control cows. A possible adverse effect of the administration of SS is the enhanced risk of the onset of metritis: $30 \%$ in SS treated cows compared to $6 \%$ of control cows [43]. This data confirms what was previously reported by Bertoni et al. [16]. This increased risk of metritis is likely a consequence of suppressed inflammatory signaling in the immune system. Indeed, the inflammation pathway is essential to activate and attract leukocytes, especially neutrophils, that are critical for the rapid clearance of pathogens [46].

\subsection{Flunixin Meglumine}

The N-methyl-D-glucamine salt of flunixin (flunixin meglumine, FM) is a NSAID drug licensed for use in cattle for the modulation of inflammation in endotoxemia and the control of pyrexia associated with tissue trauma, bovine respiratory disease, and acute bovine mastitis [47]. FM works by inhibiting both cyclooxygenase isoforms COX-1 and COX-2, but is more selective for COX-1 [35].

The terminal half-life of this NSAID is from 3.14 to $8.12 \mathrm{~h}$ after slow intravenous administration in cattle [48], and the withdrawal time for milk is $36 \mathrm{~h} \mathrm{[49]} \mathrm{(Table} \mathrm{1).} \mathrm{Some} \mathrm{studies} \mathrm{have} \mathrm{reported}$ serious side effects following the use of FM on the day of calving due to an increased risk of placental retention (RP) and metritis [38,50]. In particular, Newby et al. [38] published a large-scale study in which cows were randomly assigned to a group undergoing FM treatment and a negative control 
group. The authors found that cows treated with FM showed a greater chance of having a high temperature, generally associated with mastitis or metritis. Moreover, the authors highlighted that the administration of FM increased the risk of placental retention and stillbirth and reduced milk production (during the first 14 DIM), but did not influence dry matter intake (DMI) [38]. These two side effects seem to be related to antiprostaglandinic effects which may be specific to this NSAID. Indeed, FM preferentially inhibits COX-1 activity, which is mainly responsible for physiological functions, thus explaining the aforementioned undesirable side effects. In another study, Shwartz et al. [51] observed that periparturient cows subjected to FM treatment did not show improvement of milk production during the first 35 days in milk (DIM), and did not differ in milk fat, protein, and lactose when compared to untreated controls. The FM treatment induced an overall reduction in DMI and caused an increase in rectal temperature in the 2 days after calving [51]. Furthermore, FM treated cows show similar concentrations of plasma glucose and NEFA but significantly lower concentrations of serum nitrogen, probably due to reduced DMI in FM-treated cows [51].

Presumably, the contradictory results between the study of Newby et al. [38] and Shwartz et al. [51] could be ascribed to different FM administration schemes (see Table 2) and to different observation windows, up to 35 DIM in the work of Shwartz et al. [51]. A recent study by Giammarco et al. [52] evaluated the effects caused by a single administration of FM (intramuscular) within $12 \mathrm{~h}$ after calving on biochemical parameters, DMI, production performance and the fertility of dairy cows. This study, similar to that of Shwartz et al. [51], confirmed that milk yield and composition were not influenced by single dose FM treatment and, more importantly, that the incidence of retained placenta (RP) was drastically reduced with respect control cows, in contrast to what has been reported by other authors [38,51]. Moreover, as also reported by Shwartz et al. [51], DMI was not influenced by FM treatment. In addition, unlike previous studies, the authors did not highlight changes in body temperature. The latter results indicate that the rise in body temperature and increased risk of RP, i.e., side effects of FM, as described in other studies [38,50], could be FM dose related.

In addition, this study revealed significant differences regarding the culling rate in the period preceding 150 DIM in cows treated with FM compared to control cows (15\% vs. $25 \%$ ), suggesting that treatment with FM may be beneficial to periparturient cows when administered in a single dose. In another study, FM administration was associated with the use of combinations of broad-spectrum antibiotics (long-acting oxytetracycline and sulfadoxyne-trimethoprim) for the treatment of animals suffering with puerpueral metritis, causing a significant reduction in pyrexia and a faster clinical improvement followed by a faster uterine involution and a return to estrus [53].

In contrast, in the study of Drillich et al. [54], the association of a single administration of FM with systemic antibiotic treatment (Ceftiofur, a third-generation cephalosporin) in cows with acute puerperal metritis showed no beneficial effect regarding overall health or reproductive performance.

Overall, all of these studies concurred that FM therapy on the day of calving and immediately afterward should not be recommended due to the aforementioned side effects.

\subsection{Meloxicam}

Unlike FM, meloxicam (MEL) is predominantly a COX-2 inhibitor in horses, rats, humans, dogs, and cats [36,55]; however, its activity has not been well established in cattle. One of the characteristics of MEL is that it has a high oral bioavailability [56] and a mean plasma half-life of approximately $26 \mathrm{~h}$ in cattle [57]. If MEL is administered via injection at $0.5 \mathrm{mg} / \mathrm{kg}$ of body weight (BW), the milk withdrawal time is 5 days [57], whereas the oral use of MEL at $1 \mathrm{mg} / \mathrm{kg}$ of BW has undetectable residues in milk after $80 \mathrm{~h} \mathrm{[58]}$ (Table 1). It has been shown that cows treated parenterally with a single dose of MEL $(0.5 \mathrm{mg} / \mathrm{kg}$ of BW) $24 \mathrm{~h}$ after calving spend more time at the feed bunk, calculated as a combination of feeding visits and total feeding time; this suggests that the administration of this NSAID could reduce postpartum pain [59]. However, no effects on DMI, milk production, rectal temperature, or plasma NEFA and BHB levels after MEL administration were observed [59]. The same result was reported by another study in which MEL was administered parenterally at the same dose $(0.5 \mathrm{mg} / \mathrm{kg}$ of BW) 
as in the previous work [59] but within $6 \mathrm{~h}$ after parturition [32]. In contrast to other NSAIDs, the administration of a single dose $(0.5 \mathrm{mg} / \mathrm{kg}$ of BW) of MEL to cows immediately after calving (within $1 \mathrm{~h}$ ) did not show a higher incidence of fetal membrane retention or postpartum metritis compared to untreated animals [60]. This is most likely due to the strong affinity of MEL for COX-2 rather than COX-1 enzymes [61]. Two studies, one conducted on a small scale [31] and the other on a large scale [30], provide evidence for how dose and administration mode of meloxicam may influence milk production in opposite ways.

Carpenter et al. [31] enrolled in their study cows from 12 to $36 \mathrm{~h}$ postpartum and treated them with MEL as bolus at a dose of $1 \mathrm{mg} / \mathrm{kg}$ of BW for three consecutive days. In this study, in contrast to those of Mainau et al. [32] and Newby et al. [59,60], cows treated with MEL showed a clear increase in daily milk production that additionally resulted in a higher milk yield per lactation. Another beneficial effect of treatment with oral MEL of periparturient cows is their minor tendency to leave the herd over the first 365 days post enrolment [31].

In support of what was previously highlighted by Carpenter et al. [31] on the effectiveness of MEL on milk production, there was a large study carried out by Shock et al. [30] on 2673 cows from 20 herds in Canada. Shock et al. [30] highlighted the positive response of milk production over 120 days in lactation following the administration of this NSAID, and also observed a reduction in the onset of subclinical mastitis. In another study [62], it was found that treatment with MEL resulted in a reduced somatic cell count compared to infected cows treated only with the antibiotic [62]. Shock et al. [30] hypothesized that the anti COX-2 action of meloxicam reduces the deleterious effects of the uncontrolled inflammation that occurs postpartum and which induces an increase in acute phase proteins (e.g., haptoglobin and amyloid serum A), thereby facilitating improved immunological responses to infections [63-65]. Nevertheless, Carpenter et al. [31] observed that the decrease of somatic cell scores in the first several months of lactation did not correspond to a significant reduction of culling incidence linked to mastitis. Presumably, the significant difference in the numbers of cows enrolled in the trials could differently impact the final results.

Furthermore, treatment with a single oral dose of MEL was associated with a significant reduction in the risk of death within the first 60 days after calving [30,62]. The differences in the results obtained among the various studies could be attributed to the different modes of NSAID administration (orally vs. parenterally), different dosages ( $0.5 \mathrm{mg} / \mathrm{kg}$ vs. $1.0 \mathrm{mg} / \mathrm{Kg}$ of BW), and different sample sizes (from a minimum of 30 to 2673 cows) [30-32,59,60]. Last but not least, an important confounding factor of NSAID trials is the duration of milk production measurement and health monitoring, varying from 1 month to the whole lactation period, making difficult to compare studies. Overall, meloxicam treatment has been shown to have potential beneficial effects on milk production and cow health when administered very early after calving (within $1 \mathrm{~h}$ ) without particular side effects.

\subsection{Carprofen}

Carprofen (CA) [( \pm )-6-chloro- $\alpha$-methylcarbazole-2-acetic acid], a derivative of propionic acid, is a powerful NSAID that is well tolerated in cattle [66]. It has been found that the administration of CA to cattle has the same degree of effectiveness of FM in inhibiting COX activity, but with a higher selectivity for the COX-2 isoform. For this reason, CA appears to have a better safety margin compared to FM when used in clinical settings [67]. When CA is administered in healthy cows, this NSAID has a small distribution volume $(0.09 \mathrm{~L} / \mathrm{kg})$, relatively low systemic clearance $(2.4 \mathrm{~mL} / \mathrm{h} \mathrm{per} \mathrm{kg})$, and a long terminal half-life $(30.7 \mathrm{~h})$. Moreover, when there is an endotoxin-induced mastitis episode, the systemic clearance of CA decreases and its terminal half-life increases (43.0 h) [68].

Vangroenweghe et al. [69] observed that a single dose $(1.4 \mathrm{mg} / \mathrm{kg})$ of CA, administered as the first clinical signs worsened, in addition to antibiotic therapy with trimethoprim sulfonamide, in primiparous cows with E. coli mastitis had modest modulatory effects on some inflammatory markers but evident effects on some of the main clinical markers, such as rectal temperature (RT) and 
reticulorumenic motility. There were evident beneficial effects regarding the general clinical conditions, recovery of the milk composition, and reduction of the production of eicosanoids [69].

Table 2. Summary of studies in periparturient dairy cows reporting doses and timing of treatments with commonly-used nonsteroidal anti-inflammatory drugs (NSAIDs) investigated during the periparturient period of dairy cows.

\begin{tabular}{|c|c|c|c|c|c|}
\hline NSAIDs & $\begin{array}{c}\mathbf{N}^{\circ} \text { Total } \\
\text { Cows }\end{array}$ & Dose & Timing $^{1}$ & $\begin{array}{c}\mathrm{N}^{\circ} \text { Treatment } \\
\text { Days }\end{array}$ & References \\
\hline \multirow{5}{*}{ Salicylates } & 78 & $1.95 \mathrm{~g} / \mathrm{L}(\mathrm{os})$ & DIM 1 to 7 & 7 & [42] \\
\hline & 78 & $1.95 \mathrm{~g} / \mathrm{L}(\mathrm{os})$ & DIM 1 to 7 & 7 & [43] \\
\hline & 51 & $185 \mathrm{mg} / \mathrm{kg}$ (os) & 12 to $36 \mathrm{~h}^{2}$ & 3 & [31] \\
\hline & 56 & $125 \mathrm{~g} / \mathrm{d}$ (os) & 12 to $36 \mathrm{~h}^{2}$ & 3 & [44] \\
\hline & 22 & $15 \mathrm{~g} / \mathrm{d}+7.5 \mathrm{~g} / \mathrm{d}$ (i.m.) & DIM 1 to $3+$ DIM 4 to 5 & 5 & [16] \\
\hline \multirow{6}{*}{$\begin{array}{l}\text { Flunexin } \\
\text { meglumin }\end{array}$} & 26 & $2.2 \mathrm{mg} / \mathrm{kg}$ (i.v.) & within $5 \mathrm{~h}^{2}$ & 3 & [51] \\
\hline & 1265 & 1.1 to $2.2 \mathrm{mg} / \mathrm{kg}$ (i.v) & within $24 \mathrm{~h}^{2}$ & 2 & [38] \\
\hline & 49 & $1-5 \mathrm{~g}$ in $30 \mathrm{~mL}$ (i.m.) & immediately after caesarean & 1 & [50] \\
\hline & 60 & $2.2 \mathrm{mg} / \mathrm{kg}(\mathrm{i} . \mathrm{m})$ & within $12 \mathrm{~h}^{2}$ & 1 & [52] \\
\hline & 128 & $2.2 \mathrm{mg} / \mathrm{kg}$ (i.v.) & DIM 5 to $8^{2}$ & 2 bid +2 sid & [53] \\
\hline & 119 & $2.2 \mathrm{mg} / \mathrm{kg}$ (i.v) & DIM 4 to $5^{2}$ & 1 & [54] \\
\hline \multirow{6}{*}{ Meloxicam } & 103 & $0.5 \mathrm{mg} / \mathrm{kg}$ (s.c.) & $25.4 \mathrm{~h}^{2}$ & 1 & [59] \\
\hline & 462 & $0.5 \mathrm{mg} / \mathrm{kg}$ (s.c.) & within $1 \mathrm{~h}^{2}$ & 1 & [60] \\
\hline & 60 & $0.5 \mathrm{mg} / \mathrm{kg}$ (s.c.) & within $6 \mathrm{~h}^{2}$ & 1 & [32] \\
\hline & 51 & $\sim 1 \mathrm{mg} / \mathrm{kg}(\mathrm{os})$ & $12-36 h^{2}$ & 4 & [31] \\
\hline & 1.009 & $\sim 1 \mathrm{mg} / \mathrm{kg}$ (os) & at calving & 1 & [30] \\
\hline & 361 & $0.5 \mathrm{mg} / \mathrm{kg}$ (s.c.) & at the diagnosis of c.m. & 1 & [62] \\
\hline \multirow{4}{*}{ Carprofen } & 639 & $1.4 \mathrm{mg} / \mathrm{kg}$ (s.c.) & DIM: 1, 3, 5; DIM 19, 21, 23 & 3 & [33] \\
\hline & 213 & $1.4 \mathrm{mg} / \mathrm{kg}$ (s.c.) & DIM 21 (every 3 days) & 3 & [17] \\
\hline & 39 & $1.4 \mathrm{mg} / \mathrm{kg}$ (i.v.) & immediately after calving & 1 & [70] \\
\hline & 60 & $1.4 \mathrm{mg} / \mathrm{kg}$ (s.c.) & within $12 \mathrm{~h}^{2}$ & 1 & [52] \\
\hline
\end{tabular}

${ }^{1}$ start treatment; ${ }^{2}$ hours after calving; DIM: Day in Milk; c.m.: clinical mastitis; bid: bis in die, twice a day; sid: semel in die, once a day; i.m.: intramuscle; i.v.: intravenous: s.c.: subcutaneous; os: oral.

Priest et al. [17] noted that, in contrast to what they had hypothesized, the administration of CA between 21 and 31 DIM in cows suffering from subclinical endometritis increased neither the portion of uterine PMN at 42 DIM nor milk production, but increased rates of pregnancy in cows with high PMN and improved liver function in all cows. Assuming that the lack of effect of CA on milk production reported by Priest et al. [17] was due to too late administration of the drug, Meier et al. [33] carried out a large-scale study in which a group of 639 cows received treatment on days 1, 3, and 5, and another group on days 19, 21, and 23 after calving. However, no benefits on milk production, metabolic health indicators, or most reproductive measures were found up to 6 weeks after calving.

The aforementioned results were confirmed in a study of Giammarco et al. [52], where CA treatment did not affect milk yield or quality, dry matter intake, BW, or body condition score. Furthermore, the authors reported that CA treatment significantly affected culling rate, reducing it in the period before 150 DIM compared with control cows, but that it is less effective than FM treatment in the reduction of RP risk. In addition, cows treated with CA also showed a higher percentage of pregnancy at first insemination than untreated cows [52].

In contrast to the other studies, Stilwell et al. [70] found that the early administration of CA (within $6 \mathrm{~h}$ after calving) induced higher milk production, which began at 220 DIM, becoming significantly higher at 305 DIM in primiparous cows compared to untreated animals. Compared to untreated cows, a large number of CA-treated cows ate during the postpartum period $(21 \% \mathrm{vs} .0 \%)$, probably because CA reduces pain-associated inappetence $[71,72]$ and potentially lowers the negative energy balance that commonly occurs in early lactation. However, the number of animals returning to pregnancy after calving at 220 days was greater in the control group [70], probably because higher milk production delays the resumption of ovarian function [73]. 
Overall, although studies about the effects of CA treatment on periparturient dairy cows are scarce, those that exist suggest that this NSAID positively influences the culling risk and pregnancy at first insemination, whereas its effect on milk production is probably associated with administration timing and is limited to primiparous cows.

\section{Another Drug: Pegbovigrastim}

Different management strategies have been studied to reduce the negative effects on periparturient dairy cows' health of the dramatic metabolic changes which occur in the first phase of lactation. In recent years, a new formulation was launched in the EU and US markets: the immune-stimulant Pegbovigrastim. Pegbovigrastim is a long-acting analogue of recombinant bovine granulocyte colony-stimulating factor (bG-CSF) that increases the count and functionality of polymorphonuclear cells in dairy cows.

A phenomenon occurring during the transition period of dairy cows is the impairment of the function of neutrophils [74]. Several studies have shown that in cattle, the administration of Pegbovigrastim provides a well-tolerated approach to overcoming periparturient immune suppression, making it possible to restore normal neutrophil function [62,75]. The administration of Pegbovigrastim induces a state of neutrophilia, characterized by a 'left-shift' towards progenitor cells with a release of mature neutrophils and band cells from storage pools in bone marrow [76,77]. Pegbovigrastim is found to induce a slight decrease of red cell count and hematocrit in cows treated 7 and 21 days after calving [62,77]. The finding of normocytic, hypochromic anemia in 50\% (8/16) and 19\% (3/16) of the Pegbovigrastim treated and control cows, respectively, could indicate an increased anemic effect after treatment with this immune stimulant [77]. A relevant effect of Pegbovigrastim is its ability to enhance the transcription of cell adhesion, migration, recognition, antimicrobial activity, and inflammation cascade genes by leukocytes, which, in turn, could trigger immune cell activation, thereby improving their function [78].

There is little information about the effects of Pegbovigrastim on postpartum disease occurrence and production. A recent paper [79] analyzed the effects of Pegbovigrastim in transition dairy cows, showing a $25 \%$ greater incidence of clinical metritis and a 2.46 -fold increase in the likelihood of developing the disease in treated cows compared to controls. The increase in clinical metritis occurrence in this study agrees with data reported by Ruiz et al. [80], who observed that the administration of Pegbovigrastim resulted in greater incidence of metritis (17.6\%) and greater odds $(16.4 \%)$ of developing metritis in the first 21 days after calving. Clinical mastitis and puerperal metritis occurrence did not differ between treatments [79]. Moreover, no significant effects were registered on milk yield, fat, protein, lactose, nonfat solids [5], or somatic cells count in Pegbovigrastim-treated cows [5,79].

\section{Conclusions}

It is now clear that most dairy cows experience a subacute inflammation status for the first days after calving that is physiological, to a certain degree, as it is important for normal immunity and reproductive system function, and for homeorhetic adaptations. If the degree of inflammation exceeds a certain level, it becomes harmful, impairing lactation. In such cases, the use of NSAIDs could be beneficial. The potential benefits of the treatment of periparturient cows with NSAIDs depend by the type of drug employed and its dosage and administration mode. NSAIDs that preferentially inhibit COX-1 activity, such as salicylates and Flunexin meglumine, show important side effects like increased risk of retained placenta, culling, or metritis, even if milk production is, on average, improved. In the case of salicylates, cow inflammation levels seem to be important; in fact, in cows with high haptoglobin concentrations, the administration of salicylate positively influences milk production compared to what occurs in cows with lower haptoglobin concentrations [31,44].

Positive effects of NSAIDs, that preferentially inhibit COX-2 activity, on milk production seem to be plausible. Their influence on cows' health is well recognized, with a minor culling and death risk and mastitis incidence and with an increase of pregnancy at first insemination. 
At present, there are no irrefutable studies demonstrating the safety and efficacy of NSAIDs. Therefore, their routine use to improve milk production and dairy cow health should be carefully evaluated and possibly associated with early diagnoses of high inflammation status.

Author Contributions: Conceptualization, V.L. and D.B.; supervision, D.B.; writing一original draft, F.T. and M.R.; writing-Review \& editing, F.T., M.R. and C.P. All authors have read and agreed to the published version of the manuscript.

Funding: This research received no external funding.

Conflicts of Interest: The authors declare no conflict of interest.

\section{References}

1. Kuhla, B. Review: Pro-inflammatory cytokines and hypothalamic inflammation: Implications for insufficient feed intake of transition dairy cows. Animal 2020, 14, 65-77. [CrossRef] [PubMed]

2. Drackley, J.K.; Overton, T.R.; Douglas, G.N. Adaptations of glucose and long-chain fatty acid metabolism in liver of dairy cows during the periparturient period. J. Dairy Sci. 2001, 84, 100-112. [CrossRef]

3. Grant, R.J.; Albright, J.L. Feeding behavior and management factors during the transition period in dairy cattle. J. Anim. Sci. 1995, 73, 2791. [CrossRef] [PubMed]

4. Huzzey, J.M.; von Keyserlingk, M.A.G.; Weary, D.M. Changes in feeding, drinking, and standing behavior of dairy cows during the transition period. J. Dairy Sci. 2005, 88, 2454-2461. [CrossRef]

5. Lopreiato, V.; Minuti, A.; Trimboli, F.; Britti, D.; Morittu, V.M.; Cappelli, F.P.; Loor, J.J.; Trevisi, E. Immunometabolic status and productive performance differences between periparturient Simmental and Holstein dairy cows in response to pegbovigrastim. J. Dairy Sci. 2019, 102, 9312-9327. [CrossRef]

6. Ingvartsen, K.L. Feeding-And management-related diseases in the transition cow. Anim. Feed Sci. Tech. 2006, 126, 175-213. [CrossRef]

7. Bauman, D.E.; Bruce Currie, W. Partitioning of nutrients during pregnancy and lactation: A review of mechanisms involving homeostasis and homeorhesis. J. Dairy Sci. 1980, 63, 1514-1529. [CrossRef]

8. Kuhla, B.; Nürnberg, G.; Albrecht, D.; Görs, S.; Hammon, H.M.; Metges, C.C. Involvement of skeletal muscle protein, glycogen, and fat metabolism in the adaptation on early lactation of dairy cows. J. Proteome. Res. 2011, 10, 4252-4262. [CrossRef]

9. van Engelen, E.; de Groot, M.; Breeveld-Dwarkasing, V.; Everts, M.; van der Weyden, G.; Taverne, M.; Rutten, V. Cervical ripening and parturition in cows are driven by a cascade of pro-inflammatory cytokines. Reprod. Domest. Anim. 2009, 44, 834-841. [CrossRef]

10. Bentley, P.A.; Wall, E.H.; Dahl, G.E.; McFadden, T.B. Responses of the mammary transcriptome of dairy cows to altered photoperiod during late gestation. Physiol. Genom. 2015, 47, 488-499. [CrossRef]

11. Oliver, S.P.; Sordillo, L.M. Udder health in the periparturient period. J. Dairy Sci. 1988, 71, $2584-2606$. [CrossRef]

12. Rosenbaum, S.; Ringseis, R.; Hillen, S.; Becker, S.; Erhardt, G.; Reiner, G.; Eder, K. Genome-wide transcript profiling indicates induction of energy-generating pathways and an adaptive immune response in the liver of sows during lactation. Comp. Biochem. Phys. A 2012, 7, 370-381. [CrossRef] [PubMed]

13. Rosenbaum, S.; Ringseis, R.; Hillen, S.; Becker, S.; Erhardt, G.; Reiner, G.; Eder, K. The stress signalling pathway nuclear factor E2-related factor 2 is activated in the liver of sows during lactation. Acta Vet. Scand. 2012, 54, 59. [CrossRef] [PubMed]

14. Gregor, M.F.; Misch, E.S.; Yang, L.; Hummasti, S.; Inouye, K.E.; Lee, A.-H.; Bierie, B.; Hotamisligil, G.S. The Role of adipocyte XBP1 in metabolic regulation during lactation. Cell Rep. 2013, 3, 1430-1439. [CrossRef]

15. DiSilvestro, R.A. Plasma levels of immunoreactive ceruloplasmin and other acute phase proteins during lactation. Exp. Biol. Med. 1986, 183, 257-261. [CrossRef]

16. Bertoni, G.; Trevisi, E.; Piccioli-Cappelli, F. Effects of acetylsalicylate used in post-calving of dairy cows. Vet. Res. Commun. 2004, 28, 217-219. [CrossRef]

17. Priest, N.V.; McDougall, S.; Burke, C.R.; Roche, J.R.; Mitchell, M.; McLeod, K.L.; Greenwood, S.L.; Meier, S. The responsiveness of subclinical endometritis to a nonsteroidal anti-inflammatory drug in pasture-grazed dairy cows. J. Dairy Sci. 2013, 96, 4323-4332. [CrossRef] 
18. Humblet, M.-F.; Guyot, H.; Boudry, B.; Mbayahi, F.; Hanzen, C.; Rollin, F.; Godeau, J.-M. Relationship between haptoglobin, serum amyloid A, and clinical status in a survey of dairy herds during a 6-month period. Vet. Clin. Path. 2006, 35, 188-193. [CrossRef] [PubMed]

19. Bionaz, M.; Trevisi, E.; Calamari, L.; Librandi, F.; Ferrari, A.; Bertoni, G. Plasma Paraoxonase, health, inflammatory conditions, and liver function in transition dairy cows. J. Dairy Sci. 2007, 90, 1740-1750. [CrossRef] [PubMed]

20. Huzzey, J.M.; Duffield, T.F.; LeBlanc, S.J.; Veira, D.M.; Weary, D.M.; von Keyserlingk, M.A.G. Short communication: Haptoglobin as an early indicator of metritis. J. Dairy Sci. 2009, 92, 621-625. [CrossRef] [PubMed]

21. Graugnard, D.E.; Bionaz, M.; Trevisi, E.; Moyes, K.M.; Salak-Johnson, J.L.; Wallace, R.L.; Drackley, J.K.; Bertoni, G.; Loor, J.J. Blood immunometabolic indices and polymorphonuclear neutrophil function in peripartum dairy cows are altered by level of dietary energy prepartum. J. Dairy Sci. 2012, 95, 1749-1758. [CrossRef] [PubMed]

22. Mullins, C.R.; Mamedova, L.K.; Brouk, M.J.; Moore, C.E.; Green, H.B.; Perfield, K.L.; Smith, J.F.; Harner, J.P.; Bradford, B.J. Effects of monensin on metabolic parameters, feeding behavior, and productivity of transition dairy cows. J. Dairy Sci. 2012, 95, 1323-1336. [CrossRef] [PubMed]

23. Ametaj, B.N.; Bradford, B.J.; Bobe, G.; Nafikov, R.A.; Lu, Y.; Young, J.W.; Beitz, D.C. Strong relationships between mediators of the acute phase response and fatty liver in dairy cows. Can. J. Anim. Sci. 2005, 85, 165-175. [CrossRef]

24. Ohtsuka, H.; Koiwa, M.; Hatsugaya, A.; Kudo, K.; Hoshi, F.; Itoh, N.; Yokota, H.; Okada, H.; Kawamura, S. Relationship between serum tnf activity and insulin resistance in dairy cows affected with naturally occurring fatty liver. J. Vet. Med. Sci. 2001, 63, 1021-1025. [CrossRef]

25. Bradford, B.J.; Yuan, K.; Farney, J.K.; Mamedova, L.K.; Carpenter, A.J. Invited review: Inflammation during the transition to lactation: New adventures with an old flame. J. Dairy Sci. 2015, 98, 6631-6650. [CrossRef]

26. Huzzey, J.M.; Mann, S.; Nydam, D.V.; Grant, R.J.; Overton, T.R. Associations of peripartum markers of stress and inflammation with milk yield and reproductive performance in Holstein dairy cows. Prev. Vet. Med. 2015, 120, 291-297. [CrossRef]

27. Yuan, K.; Farney, J.K.; Mamedova, L.K.; Sordillo, L.M.; Bradford, B.J. TNF $\alpha$ altered inflammatory responses, impaired health and productivity, but did not affect glucose or lipid metabolism in early-lactation dairy cows. PLoS ONE 2013, 8, e80316. [CrossRef]

28. Sugimoto, Y.; Yamasaki, A.; Segi, E.; Tsuboi, K.; Aze, Y.; Nishimura, T.; Oida, H.; Yoshida, N.; Tanaka, T.; Katsuyama, M.; et al. Failure of parturition in mice lacking the prostaglandin F receptor. Science 1997, 277, 681-683. [CrossRef]

29. Newton, K.; Dixit, V.M. Signaling in innate immunity and inflammation. Cold Spring Harb. Perspect. Biol. 2012, 4, 006049. [CrossRef]

30. Shock, D.A.; Renaud, D.L.; Roche, S.M.; Poliquin, R.; Thomson, R.; Olson, M.E. Evaluating the impact of meloxicam oral suspension administered at parturition on subsequent production, health, and culling in dairy cows: A randomized clinical field trial. PLoS ONE 2018, 13, e0209236. [CrossRef]

31. Carpenter, A.J.; Ylioja, C.M.; Vargas, C.F.; Mamedova, L.K.; Mendonça, L.G.; Coetzee, J.F.; Hollis, L.C.; Gehring, R.; Bradford, B.J. Hot topic: Early postpartum treatment of commercial dairy cows with nonsteroidal anti-inflammatory drugs increases whole-lactation milk yield. J. Dairy Sci. 2016, 99, 672-679. [CrossRef] [PubMed]

32. Mainau, E.; Cuevas, A.; Ruiz-de-la-Torre, J.L.; Abbeloos, E.; Manteca, X. Effect of meloxicam administration after calving on milk production, acute phase proteins, and behavior in dairy cows. J. Vet. Behav. 2014, 9, 357-363. [CrossRef]

33. Meier, S.; Priest, N.V.; Burke, C.R.; Kay, J.K.; McDougall, S.; Mitchell, M.D.; Walker, C.G.; Heiser, A.; Loor, J.J.; Roche, J.R. Treatment with a nonsteroidal anti-inflammatory drug after calving did not improve milk production, health, or reproduction parameters in pasture-grazed dairy cows. J. Dairy Sci. 2014, 97, 2932-2943. [CrossRef]

34. Vane, J.R.; Botting, R.M. Mechanism of action of anti-inflammatory drugs. Scand. J. Rheumatol. Suppl. 1996, 25, 9-21. [CrossRef] [PubMed] 
35. Lees, P.; Landoni, M.F.; Giraudel, J.; Toutain, P.L. Pharmacodynamics and pharmacokinetics of nonsteroidal anti-inflammatory drugs in species of veterinary interest. J. Vet. Pharmacol. Ther. 2004, 27, 479-490. [CrossRef] [PubMed]

36. Beretta, C.; Garavaglia, G.; Cavalli, M. COX-1 and COX-2 inhibition in horse blood by phenylbutazone, flunixin, carprofen and meloxicam: An in vitro analysis. Pharmacol. Res. 2005, 52, 302-306. [CrossRef] [PubMed]

37. Cryer, B.; Feldman, M. Cyclooxygenase-1 and Cyclooxygenase-2 selectivity of widely used nonsteroidal anti-inflammatory drugs. Am. J. Med. 1998, 104, 413-421. [CrossRef]

38. Newby, N.C.; Leslie, K.E.; Dingwell, H.D.P.; Kelton, D.F.; Weary, D.M.; Neuder, L.; Millman, S.T.; Duffield, T.F. The effects of periparturient administration of flunixin meglumine on the health and production of dairy cattle. J. Dairy Sci. 2017, 100, 582-587. [CrossRef]

39. Mitchell, J.A.; Akarasereenont, P.; Thiemermann, C.; Flower, R.J.; Vane, J.R. Selectivity of nonsteroidal anti-inflammatory drugs as inhibitors of constitutive and inducible cyclooxygenase. Proc. Natl. Acad. Sci. USA 1993, 90, 11693-11697. [CrossRef] [PubMed]

40. Yin, M.-J.; Yamamoto, Y.; Gaynor, R.B. The anti-inflammatory agents aspirin and salicylate inhibit the activity of IкB kinase- $\beta$. Nature 1998, 396, 77-80. [CrossRef]

41. Veterinary Medicine Expert Committee on Drug Information, United States Pharmacopeia. USP veterinary pharmaceutical information monographs-Anti-inflammatories. J. Vet. Pharmacol. Ther. 2004, 27, 6-14. [CrossRef]

42. Farney, J.K.; Mamedova, L.K.; Coetzee, J.F.; KuKanich, B.; Sordillo, L.M.; Stoakes, S.K.; Minton, J.E.; Hollis, L.C.; Bradford, B.J. Anti-inflammatory salicylate treatment alters the metabolic adaptations to lactation in dairy cattle. Am. J. Physiol. Regul. Integr. Comp. Physiol. 2013, 305, 110-117. [CrossRef] [PubMed]

43. Farney, J.K.; Mamedova, L.K.; Coetzee, J.F.; Minton, J.E.; Hollis, L.C.; Bradford, B.J. Sodium salicylate treatment in early lactation increases whole-lactation milk and milk fat yield in mature dairy cows. J. Dairy Sci. 2013, 96, 7709-7718. [CrossRef] [PubMed]

44. Carpenter, A.J.; Ylioja, C.M.; Mamedova, L.K.; Olagaray, K.E.; Bradford, B.J. Effects of early postpartum sodium salicylate treatment on long-term milk, intake, and blood parameters of dairy cows. J. Dairy Sci. 2018, 101, 1437-1447. [CrossRef] [PubMed]

45. Rebholz, S.L.; Jones, T.; Burke, K.T.; Jaeschke, A.; Tso, P.; D'Alessio, D.A.; Woollett, L.A. Multiparity leads to obesity and inflammation in mothers and obesity in male offspring. Am. J. Physiol. Endocrinol. Metab. 2012, 302, 449-457. [CrossRef] [PubMed]

46. Kolaczkowska, E.; Kubes, P. Neutrophil recruitment and function in health and inflammation. Nat. Rev. Immunol. 2013, 13, 159-175. [CrossRef]

47. Food and Drug Administration. Freedom of Information Summary: Supplemental New Animal Drug Application (NADA101-479). 2004. Available online: https://animaldrugsatfda.fda.gov/adafda/app/search/ public/document/downloadFoi/355 (accessed on 23 June 2020).

48. Anderson, K.L.; Neff-Davis, C.A.; Davis, L.E.; Bass, V.D. Pharmacokinetics of flunixin meglumine in lactating cattle after single and multiple intramuscular and intravenous administrations. Am. J. Vet. Res. 1990, 51, 1464-1467.

49. Kissell, L.W.; Smith, G.W.; Leavens, T.L.; Baynes, R.E.; Wu, H.; Riviere, J.E. Plasma pharmacokinetics and milk residues of flunixin and 5-hydroxy flunixin following different routes of administration in dairy cattle. J. Dairy Sci. 2012, 95, 7151-7157. [CrossRef]

50. Waelchli, R.O.; Thun, R.; Stocker, H. Effect of flunixin meglumine on placental expulsion in dairy cattle after a caesarean. Vet. Rec. 1999, 144, 702-703. [CrossRef]

51. Shwartz, G.; Hill, K.L.; VanBaale, M.J.; Baumgard, L.H. Effects of flunixin meglumine on pyrexia and bioenergetic variables in postparturient dairy cows. J. Dairy Sci. 2009, 92, 1963-1970. [CrossRef]

52. Giammarco, M.; Fusaro, I.; Vignola, G.; Manetta, A.C.; Gramenzi, A.; Fustini, M.; Palmonari, A.; Formigoni, A. Effects of a single injection of Flunixin meglumine or Carprofen postpartum on haematological parameters, productive performance and fertility of dairy cattle. Anim. Prod. Sci. 2018, 58, 322. [CrossRef]

53. Amiridis, G.S.; Leontides, L.; Tassos, E.; Kostoulas, P.; Fthenakis, G.C. Flunixin meglumine accelerates uterine involution and shortens the calving-to-first-oestrus interval in cows with puerperal metritis. J. Vet. Pharmacol. Ther. 2001, 24, 365-367. [CrossRef] [PubMed] 
54. Drillich, M.; Klever, N.; Heuwieser, W. Comparison of two management strategies for retained fetal membranes on small dairy farms in Germany. J. Dairy Sci. 2007, 90, 4275-4281. [CrossRef] [PubMed]

55. Brideau, C.; Van Staden, C.; Chan, C.C. In vitro effects of cyclooxygenase inhibitors in whole blood of horses, dogs, and cats. Am. J. Vet. Res. 2001, 62, 1755-1760. [CrossRef]

56. Mathews, K.A. Nonsteroidal anti-inflammatory analgesics. Indications and contraindications for pain management in dogs and cats. Vet. Clin. Small Anim. Pract. 2000, 30, 783-804. [CrossRef]

57. European Agency for the Evaluation of Medicinal Products. Scientific Discussion, Metacam. CVMP/323/97: London, UK, 2007. Available online: https://www.ema.europa.eu/en/documents/scientific-discussion/ metacam-epar-scientific-discussion_en.pdf (accessed on 24 June 2020).

58. Malreddy, P.R.; Coetzee, J.F.; Kukanich, B.; Gehring, R. Pharmacokinetics and milk secretion of gabapentin and meloxicam co-administered orally in Holstein-Friesian cows. J. Vet. Pharmacol. Ther. 2013, 36, 14-20. [CrossRef]

59. Newby, N.C.; Pearl, D.L.; LeBlanc, S.J.; Leslie, K.E.; von Keyserlingk, M.A.G.; Duffield, T.F. Effects of meloxicam on milk production, behavior, and feed intake in dairy cows following assisted calving. J. Dairy Sci. 2013, 96, 3682-3688. [CrossRef]

60. Newby, N.C.; Renaud, D.; Tremblay, R.; Duffield, T.F. Evaluation of the effects of treating dairy cows with meloxicam at calving on retained fetal membranes risk. Can. Vet. J. 2014, 55, 1196-1199.

61. Manteca, X.E.; Mainau, E.; Cuevas, A.; Ruiz de la Torre, J.L. The effect of parity and time on pain and discomfort associated with normal calving in dairy cows. In Proceedings of the 3rd Expert Forum on Farm Animal Well-Being, Barcelona, Spain, 4 June 2010; School of Veterinary Science, Universitat Autònoma de Barcelona: Barcelona, Spain, 2010.

62. McDougall, S.; LeBlanc, S.J.; Heiser, A. Effect of prepartum energy balance on neutrophil function following pegbovigrastim treatment in periparturient cows. J. Dairy Sci. 2017, 100, 7478-7492. [CrossRef]

63. Tóthová, C.; Nagy, O.; Kovác, G. Changes in the concentrations of selected acute phase proteins and variables of energetic profile in dairy cows after parturition. J. Appl. Anim. Res. 2014, 42, 278-283. [CrossRef]

64. Pohl, A.; Burfeind, O.; Heuwieser, W. The associations between postpartum serum haptoglobin concentration and metabolic status, calving difficulties, retained fetal membranes, and metritis. J. Dairy Sci. 2015, 98, 4544-4551. [CrossRef] [PubMed]

65. Akbar, H.; Grala, T.M.; Vailati Riboni, M.; Cardoso, F.C.; Verkerk, G.; McGowan, J.; Macdonald, K.; Webster, J.; Schutz, K.; Meier, S. Body condition score at calving affects systemic and hepatic transcriptome indicators of inflammation and nutrient metabolism in grazing dairy cows. J. Dairy Sci. 2015, 98, 1019-1032. [CrossRef] [PubMed]

66. Ludwig, B.; Jordan, J.C.; Rehm, W.F.; Thun, R. Carprofen in veterinary medicine. I. Plasma disposition, milk excretion and tolerance in milk-producing cows. Schweizer Archiv Tierheilkunde 1989, 131, 99-106.

67. Miciletta, M.; Cuniberti, B.; Barbero, R.; Re, G. In vitro enantioselective pharmacodynamics of Carprofen and Flunixin-meglumine in feedlot cattle. J. Vet. Pharmacol. Ther. 2014, 37, 43-52. [CrossRef] [PubMed]

68. Lohuis, J.A.C.M.; Werven, T.; Brand, A.; Miert, A.S.J.P.A.M.; Rohde, E.; Ludwig, B.; Heizmann, P.; Rehm, W.F. Phmacodynamics and pharmacokinetics of carprofen, a non-steroidal anti-inflammatory drug, in healthy cows and cows with Escherichia coli endotoxin-induced mastitis. J. Vet. Pharmacol. Ther. 1991, 14, $219-229$. [CrossRef]

69. Vangroenweghe, F.; Duchateau, L.; Boutet, P.; Lekeux, P.; Rainard, P.; Paape, M.J.; Burvenich, C. Effect of carprofen treatment following experimentally induced Escherichia coli mastitis in primiparous cows. J. Dairy Sci. 2005, 88, 2361-2376. [CrossRef]

70. Stilwell, G.; Schubert, H.; Broom, D.M. Short communication: Effects of analgesic use postcalving on cow welfare and production. J. Dairy Sci. 2014, 97, 888-891. [CrossRef]

71. Pang, W.Y.; Earley, B.; Sweeney, T.; Crowe, M.A. Effect of carprofen administration during banding or burdizzo castration of bulls on plasma cortisol, in vitro interferon- $\gamma$ production, acute-phase proteins, feed intake, and growth1. J. Anim. Sci. 2006, 84, 351-359. [CrossRef]

72. Stilwell, G.; Lima, M.S.; Broom, D.M. Effects of nonsteroidal anti-inflammatory drugs on long-term pain in calves castrated by use of an external clamping technique following epidural anesthesia. Am. J. Vet. Res. 2008, 69, 744-750. [CrossRef] 
73. Walsh, R.B.; Walton, J.S.; Kelton, D.F.; LeBlanc, S.J.; Leslie, K.E.; Duffield, T.F. The Effect of subclinical ketosis in early lactation on reproductive performance of postpartum dairy cows. J. Dairy Sci. 2007, 90, 2788-2796. [CrossRef]

74. Rinaldi, M.; Moroni, P.; Paape, M.J.; Bannerman, D.D. Differential alterations in the ability of bovine neutrophils to generate extracellular and intracellular reactive oxygen species during the periparturient period. Vet. J. 2008, 178, 208-213. [CrossRef] [PubMed]

75. Zinicola, M.; Korzec, H.; Teixeira, A.G.V.; Ganda, E.K.; Bringhenti, L.; Tomazi, A.C.C.H.; Gilbert, R.O.; Bicalho, R.C. Effects of pegbovigrastim administration on periparturient diseases, milk production, and reproductive performance of Holstein cows. J. Dairy Sci. 2018, 101, 11199-11217. [CrossRef] [PubMed]

76. Van Schyndel, S.J.; Carrier, J.; Bogado Pascottini, O.; LeBlanc, S.J. The effect of pegbovigrastim on circulating neutrophil count in dairy cattle: A randomized controlled trial. PLoS ONE 2018, 13, e0198701. [CrossRef] [PubMed]

77. Trimboli, F.; Morittu, V.M.; Di Loria, A.; Minuti, A.; Spina, A.A.; Piccioli-Cappelli, F.; Trevisi, E.; Britti, D.; Lopreiato, V. Effect of pegbovigrastim on hematological profile of simmental dairy cows during the transition period. Animals 2019, 9, 841. [CrossRef]

78. Lopreiato, V.; Palma, E.; Minuti, A.; Loor, J.J.; Lopreiato, M.; Trimboli, F.; Morittu, M.V.; Spina, A.A.; Britti, D.; Trevisi, E. Pegbovigrastim treatment around parturition enhances postpartum immune response gene network expression of whole blood leukocytes in Holstein and Simmental cows. Animals 2020, 10, 621. [CrossRef]

79. Oliveira, M.X.S.; McGee, D.D.; Brett, J.A.; Larson, J.E.; Stone, A.E. Evaluation of production parameters and health of dairy cows treated with pegbovigrastim in the transition period. Prev. Vet. Med. 2020, 176, 104931. [CrossRef]

80. Ruiz, R.; Tedeschi, L.O.; Sepúlveda, A. Investigation of the effect of pegbovigrastim on some periparturient immune disorders and performance in Mexican dairy herds. J. Dairy Sci. 2017, 100, 3305-3317. [CrossRef]

(C) 2020 by the authors. Licensee MDPI, Basel, Switzerland. This article is an open access article distributed under the terms and conditions of the Creative Commons Attribution (CC BY) license (http://creativecommons.org/licenses/by/4.0/). 